Primljen / Received: 18.6.2013.

Ispravljen / Corrected: 28.9.2013.

Prihvaćen / Accepted: 7.10.2013.

Dostupno online / Available online: 10.12.2013.

\title{
Local and global effects of forward directivity
}

\section{Authors:}

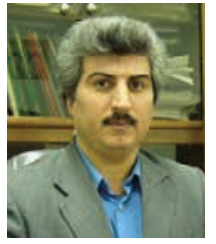

Assoc.Prof. Mohsen Gerami, PhD. CE

University of Semnan

Faculty of Civil Engineering

mgerami@semnan.ac.ir

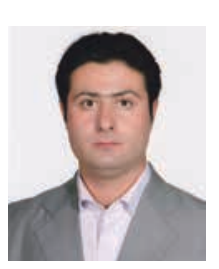

Davood Abdollahzadeh, MSc. CE

University of Semnan

Faculty of Civil Engineering

d_abd87@semnan.ac.ir

\section{Mohsen Gerami, Davood Abdollahzadeh}

\section{Local and global effects of forward directivity}

Previous studies have revealed that near-fault ground motions perpendicular to the fault slip are very destructive for structures. Due to the common use of moment resisting frames and the importance of near-fault strong motions, the local and global effects of long-period (Tpulse $>0.7 \mathrm{~s}$ ) pulse-like ground motions are studied on 5 samples of steel moment resisting frames by considering variations in the height of models. Results obtained show the forward directivity increases global and local demands of models for about 1.1 to 2.6 , and 1.2 to 3.5 times, respectively.

Key words:

near fault earthquake, steel moment resisting frames, pulse-like motions, seismic evaluation

\section{Mohsen Gerami, Davood Abdollahzadeh}

Izvorni znanstveni rad

\section{Lokalne i globalne posljedice primarnog udara}

Ranija istraživanja pokazuju da pomaci tla u blizini rasjeda djeluju vrlo destruktivno na građevine smještene poprečno na plohu loma rasjeda. Zbog uobičajenog korištenja okvira otpornih na savijanje te zbog značaja snažnih pomaka u blizini rasjeda, u ovom se radu razmatraju utjecaji pulsirajućih pomaka tla dugog perioda (Tpulse>0,7s) na lokalno i globalno ponašanje pet uzoraka čeličnih okvira otpornih na savijanje, uzimajući u obzir varijacije zbog promjene visine modela. Rezultati pokazuju da se kod primarnog udara globalni i lokalni zahtjevi modela povećavaju za 1,1 do 2,6 puta tj. za 1,2 do 3,5 puta.

Ključne riječi:

bliski potres, čelični okviri otporni na savijanje, pulsirajuči pomaci, seizmička ocjena

Wissenschaftlicher Originalbeitrag

\section{Mohsen Gerami, Davood Abdollahzadeh}

\section{Lokale und globale Effekte der Vorwärtsrichtwirkung}

Vorherige Untersuchungen haben gezeigt, dass nahe an Verwerfungen und orthogonal zur Bruchfläche auftretende Erdbeben starke destruktive Auswirkungen auf Konstruktionen haben können. Aufgrund des üblichen Einsatzes von Rahmenkonstruktionen und der Bedeutung von Erdbeben in Verwerfungszonen, sind in dieser Arbeit die Effekte pulsartiger Bodenbewegungen langer Perioden (Tpulse>0.7s) untersucht. Der Einfluss auf das globale und lokale Verhalten ist an fünf Beispielen von Stahlrahmenkonstruktionen verschiedener Höhen erforscht. Die Resultate zeigen, dass globale und lokale Anforderungen der Modelle durch Vorwärtsrichtwirkung mehrfach ansteigen können (1.1 bis 2.6, bzw. 1.2 bis 3.5-fach). 


\section{Introduction}

Previous studies have demonstrated that the directivity of a fault fracture causes different effects in near field ground motions compared to far-fault earthquakes [1-6]. Comparing the forward directivity and the backward directivity in the near field of fault, the forward directivity usually has the highest effects on engineering structures $[3,4]$. In regions located near active faults (usually less than $15 \mathrm{~km}$ away from the fault), the forward directivity causes pulse-like ground motions with a high amplitude and long period normal to the rupture plate of the fault, in such a way that the pulse like motion is visible in the velocity time history. After destructive earthquakes such as Landers (1992), Northridge (1994), and Kobe (1995), it was established that structures designed according to modern seismic codes experience severe damage due to the forward directivity effect [7]. Because of near fault importance, many researchers have studied the inelastic response of buildings in case of near-fault motions. They showed that by increasing two parameters: the ratio of pulse period to the natural period of structures, and the ratio of Peak Ground Acceleration (PGA) to lateral stiffness of structures, the non-linear response and damage to structures increase in near fault regions. In addition, the concentration of displacements at lower parts of structures causes axial force increase in columns, while the P- $\Delta$ effect intensifies at lower storeys of structures [8]. J. F. Hall (1997) investigated the effect of the near fault ground motion on low and high-rise moment frames. He pointed out that the residual strength in damaged connections, undamaged connections after earthquake, structure-slab interaction, girder axial strength, strength of simple connections in gravity frames, higher strength of steel and strain hardening, have caused the structures stability after near field ground motions [9].

Because of the existence of some populated cities and metropolises near active earthquake sources, and due to severity of near source motions, the study of the near fault ground motion effects is still under way, and the objective is to achieve better understanding of the behaviour of structures located in the near fault regions. Relevant studies have revealed that the behaviour of structures and the damage pattern may differ depending on the structure specification and ground motion characteristics in near field of the fault, [10-13]. Other researches are related to the development of new modelling approaches focusing on near fault effects in the loading pattern, and on design regulations [12]. These researches should lead to the development of some criteria for the seismic design of new structures in the near field of the fault. The 1997 Uniform Building Code (UBC97) is a pioneer in this significant topic. It provides some coefficients for considering near fault effects in the calculation of shear at the base of structures [13]. After Bam earthquake (2003), the Iranian Seismic Design Code (Standard No.2800, $3^{\text {rd }}$ edition) was prepared in Iran in 2005 by the Ministry of Housing and
Urban Development of Iran. In this edition of the Iranian Seismic Code, it is only recommended to avoid constructing buildings in the vicinity or near active faults. However, in the cases when buildings have to be built close to an active fault, some special technical advices must be considered, but none of these advices are specified in the Iranian code.

After the Bam earthquake (2003), observations and field studies have shown that most of buildings were damaged at the ground floor level, and in the direction normal to the fault line [14-18]. Additional studies [16-19] on Bam earthquake (2003) have shown severe effects of forward directivity on frame structures. In order to continue with the studies on the effects of near fault ground motions on structures, and in the light of the above mentioned reasons, the forward directivity effects on the local and global behaviour of moment frames will be analyzed in this study. The effects of long-period pulse-like motions have been investigated with regard to the base shear, drift, demand and capacity of columns and girders, moment forces and bending ductility by means of the nonlinear time history analysis conducted on five structural models. These structural models are $2 \mathrm{D}$ steel moment frames with 3, 5, 7, 10 and 15 storeys, which were analyzed using the nonlinear dynamic analysis based on FEMA 356 provisions regarding 20 earthquake records. In addition, the effect of intensification of forward directivity on the axial force of columns was also investigated with respect to variations in the aspect ratio of the structure.

\section{Research assumptions and modeling}

\subsection{Selection of earthquake records}

In case of an earthquake, different effects are observed in terms of both the shape and type of motion in different regions around a seismic fault, which is dependent on the mechanism and directivity of the fault rupture. The fault rupture propagation directivity with respect to the site can be either forward or backward. Under conditions in which the fault rupture propagation velocity is almost equal to the propagation velocity of earthquake waves, and the fault rupture propagation direction is toward the site, the accumulation of waves from each rupture causes 1 to 3 pulses with long period and high amplitude in the component normal to the fault plane, which then vibrate near-fault regions in a short effective time $[2$, 23]. Therefore, the forward directivity effect causes pulse-like records normal to direction of the fault line. If the fault rupture propagates away from the site, the ground vibrates with a relatively high number of low-amplitude oscillations. This situation is called backward directivity. Other regions without the forward or backward directivity effect are called regions with a neutral directivity effect [20].

Based on the studies by Alavi and Krawinkler (2001) [3], and in order to consider the forward directivity effects according to the mentioned definitions, ten records were selected 
Table 1. Earthqauke records used in this study

\begin{tabular}{|c|c|c|c|c|c|c|c|c|c|}
\hline $\begin{array}{l}\text { Earthquake name } \\
\text { Date (yy-mm-dd) }\end{array}$ & Station & Com.-Azi. ${ }^{a}$ & $\begin{array}{c}\mathbf{R}^{\mathrm{b}} \\
{[\mathrm{km}]}\end{array}$ & $\begin{array}{l}\text { PGA }^{c} \\
{[\mathrm{~g}]}\end{array}$ & $\begin{array}{c}\text { PGV/ } \\
\text { PGA }^{d} \\
{[s]}\end{array}$ & $\begin{array}{c}\text { SEDe } \\
{\left[\mathrm{m}^{2} / \mathrm{s}\right]}\end{array}$ & $\begin{array}{l}\text { CAV }^{f} \\
{[\mathrm{~m} / \mathrm{s}]}\end{array}$ & $\begin{array}{l}\mathrm{Tpg} \\
{[\mathrm{s}]}\end{array}$ & $\begin{array}{c}\operatorname{Tm}^{\mathrm{h}} \\
{[\mathrm{s}]}\end{array}$ \\
\hline Chi-Chi, Taiwan 99-09-20 & CHY065 & $\mathrm{N}-\mathrm{O}^{\circ}$ & 83.43 & 0.1 & 0.14 & 0.09 & 9.88 & 0.56 & 0.79 \\
\hline Chi-Chi, Taiwan 99-09-20 & TAP095 & $\mathrm{E}-90^{\circ}$ & 109.01 & 0.15 & 0.18 & 4.66 & 56.56 & 0.98 & 0.84 \\
\hline Loma Prieta 89-10-18 & CDMG58224 & $290^{\circ}$ & 72.2 & 0.24 & 0.15 & 1.88 & 27.69 & 0.32 & 0.86 \\
\hline Loma Prieta 89-10-18 & CDMG58472 & $270^{\circ}$ & 74.26 & 0.26 & 0.16 & 2.12 & 28.35 & 0.64 & 0.85 \\
\hline Kobe, Japan 95-01-16 & HIK & $0^{\circ}$ & 95.72 & 0.14 & 0.11 & 2.08 & 45.02 & 0.6 & 0.76 \\
\hline Loma Prieta 89-10-18 & CDMG58223 & $0^{\circ}$ & 58.65 & 0.23 & 0.11 & 1.02 & 33.26 & 0.3 & 0.53 \\
\hline Manjil, Iran 90-06-20 & Qazvin & $336^{\circ}$ & 49.97 & 0.13 & 0.09 & 2.54 & 59.48 & 0.16 & 0.46 \\
\hline Northridge 94-01-17 & CDMG13122 & $0^{\circ}$ & 82.32 & 0.10 & 0.07 & 0.50 & 31.22 & 0.38 & 0.44 \\
\hline Tabas, Iran 78-09-16 & Ferdows & T1 & 91.14 & 0.10 & 0.08 & 2.18 & 48.38 & 0.24 & 0.29 \\
\hline Kocaeli, Turkey 99-08-17 & Bursa Tofas & $90^{\circ}$ & 60.43 & 0.10 & 0.21 & 11.40 & 100.90 & 0.68 & 0.93 \\
\hline Denali, Alaska 02-11-03 & Pump St.10 & $47^{\circ}$ & 2.74 & 0.32 & 0.43 & 19.79 & 47.83 & 0.94 & 1.52 \\
\hline Bam, Iran 03-12-26 & Bam & $\mathrm{T} 3-8^{\circ}$ & $R<15$ & 0.59 & 0.43 & 41.96 & 118.26 & 0.78 & 0.91 \\
\hline Chi-Chi, Taiwan 99-09-20 & CHY101 & $\mathrm{N}-\mathrm{O}^{\circ}$ & 9.96 & 0.44 & 0.27 & 13.27 & 48.15 & 0.9 & 0.98 \\
\hline Chi-Chi, Taiwan 99-09-20 & TCU068 & $\mathrm{E}-90^{\circ}$ & 0.32 & 0.56 & 0.32 & 36.53 & 30.52 & 0.42 & 1.51 \\
\hline Imperial Valley 79-10-15 & CDMG 5158 & $230^{\circ}$ & 1.35 & 0.43 & 0.26 & 7.64 & 23.33 & 0.24 & 1.31 \\
\hline Northridge 94-01-17 & DWP 75 & $288^{\circ}$ & 5.19 & 0.49 & 0.15 & 2.04 & 25.50 & 0.22 & 0.72 \\
\hline Silakhor, Iran 06-03-31 & Chalan Cho. & $\mathrm{L}-99^{\circ}$ & $\mathrm{R}<15$ & 0.45 & 0.33 & 52.61 & 93.81 & 1.52 & 1.82 \\
\hline Kocaeli, Turkey 99-08-17 & Yarimca & $60^{\circ}$ & 4.83 & 0.26 & 0.25 & 19.93 & 39.12 & 0.52 & 1.29 \\
\hline Zanjiran, Iran 94-06-20 & Meymand & $\mathrm{L}-0^{\circ}$ & $R<15$ & 0.42 & 0.28 & 44.69 & 123.41 & 1.36 & 1.73 \\
\hline Kobe, Japan 95-01-16 & Takatori & $0^{\circ}$ & 1.47 & 0.61 & 0.21 & 6.34 & 42.52 & 1.22 & 1.10 \\
\hline $\begin{array}{l}\text { a Component-Azimuth, }{ }^{\text {b }} \text { Clo } \\
\text { Ground Acceleration Rati }\end{array}$ & $\begin{array}{l}\text { istance from } t \\
\text { ecific Energy }\end{array}$ & cording s & the rup & area & KGro & CEIEI & Peak $C$ & d Velc & $\begin{array}{l}\text { o Peal } \\
{[22]}\end{array}$ \\
\hline
\end{tabular}

from the regions located less than 15 kilometers away from active faults, which were pulse-like and had long periods and large magnitudes in the velocity time historey [3, 27]. In addition from two horizontal components recorded in each accelerogram station, the component having higher values of acceleration response spectrum in the long-period range ( $T>1 \mathrm{~s})$ was selected. In order to compare the results of the near and far field of fault, ten records in the far field of fault with neutral directivity were selected. All earthquake records were chosen from famous world earthquakes with the moment magnitude of higher than 6.5. To avoid errors arising from records in the regions situated very far away from the fault, the value of $0.1 \mathrm{~g}$ was adopted as the minimum PGA value. Since the forward directivity has higher effects in soil sites, all records were selected from the stiff soil sites (Class $D$ based on FEMA 356 soil classification [26]). The records used in this study are presented in Table 1. Past studies have shown that the forward directivity causes the amplitude of velocity response spectrum increase in the period range of more than 0.6 to 1.1 seconds, in such a way that in the grounds with stiff soils in the period range of $2 \mathrm{~s}$ the amplitude of response spectrum increases to the value that is two times greater than that registered in the far-fault region [21].

\subsection{Structural models}

Five two-dimensional models of special steel moment frame were designed in sites characterized by stiff soil conditions, as shown in Figure 1. The models are moment frames with 3, 5, 7, 10 and 15 storeys, $5 \mathrm{~m}$ span length, and 3.2m storey height. Steel materials types ST37 and ST52, manufactured by Esfahan steel company, are nowadays used to construct steel structures in Iran. Therefore, based on steel material specifications provided by Iranian code [28], the steel type ST37, with the yield point of $2400 \mathrm{~kg} / \mathrm{cm}^{2}$ and ultimate stress of $3600 \mathrm{~kg} / \mathrm{cm}^{2}$, is considered for the design and evaluation of the models. Iranian seismic design code offers peak ground acceleration of $0.35 \mathrm{~g}$ for high seismic hazard level regions with $10 \%$ probability of earthquake event in the 50 years of useful life of a building [25]. The seismic code does not provide a different PGA for near source earthquakes. In other words, based on Iranian code, and given the same hazard level, the peak ground acceleration (PGA) is equal for both the near and far fields of a fault. The seismic loading of models was done based on the $3^{\text {rd }}$ edition of the Iranian seismic design code for the regions with high rate of seismicity and with maximum PGA of $0.35 \mathrm{~g}$. The dead and live loads of storeys, except for the roof, are the 


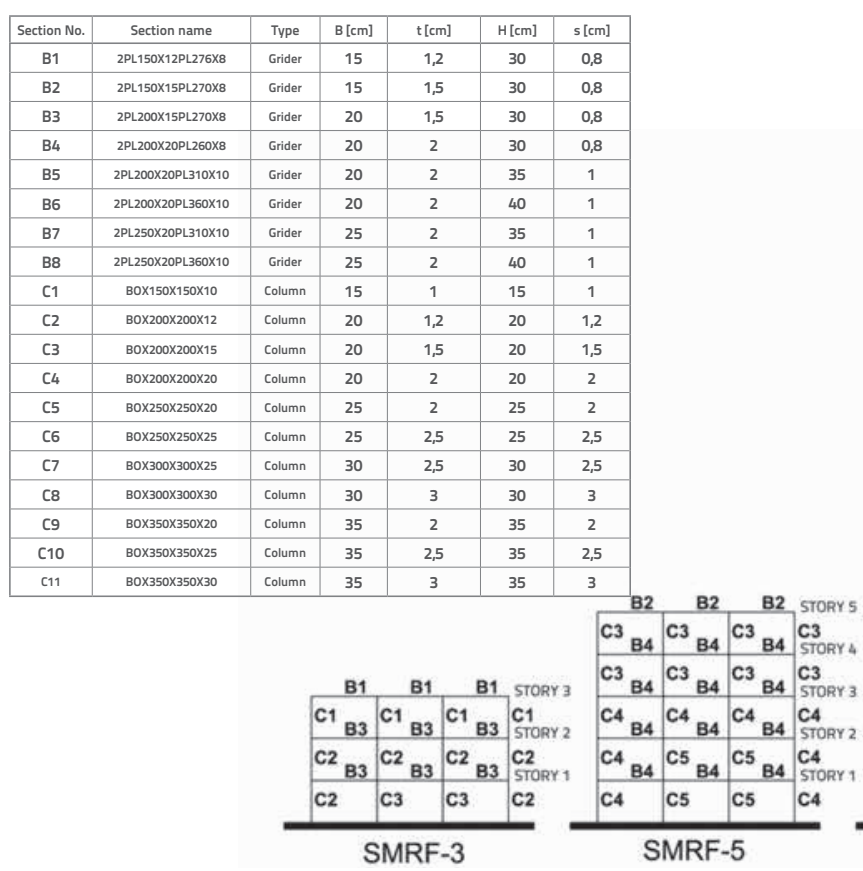

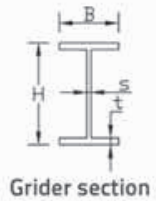

Stories height $=320 \mathrm{~cm}$ Spans length $=500 \mathrm{~cm}$

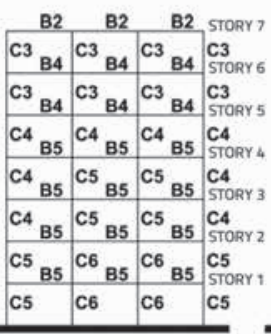
SMRF-7

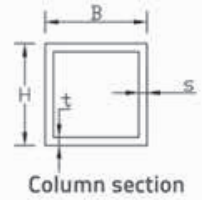

$\begin{array}{llll}\text { B2 } & \text { B2 } \quad \text { B2 } & \text { STORY } 10\end{array}$

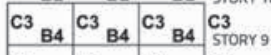

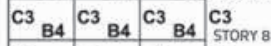

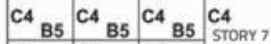

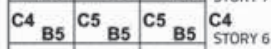

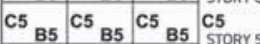

\begin{tabular}{|l|l|l|l|l|}
\hline${ }^{C 5}{ }_{B 7}$ & $\mathrm{C6}{ }_{\mathrm{B7}}$ & ${ }^{\mathrm{C} 6}{ }_{\mathrm{B} 7}$ & $\begin{array}{l}\text { C5 } \\
\text { STORY } 4\end{array}$ \\
\hline
\end{tabular}

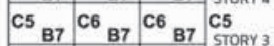

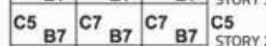

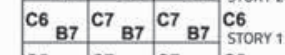

\begin{tabular}{l|l|l|l} 
C6 & C7 & C7 & C6
\end{tabular}

SMRF-10

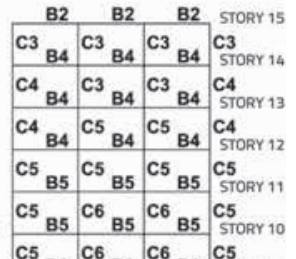

\begin{tabular}{l|l|l|l}
${ }^{\mathrm{C} 5}{ }_{\mathrm{B} 6}$ & ${ }^{\mathrm{C} 6}{ }_{\mathrm{B} 6}$ & ${ }^{\mathrm{C} 6}{ }_{\mathrm{B} 6}$ & ${ }_{\text {STORY9 }}$
\end{tabular}

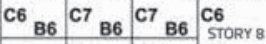

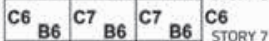

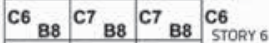

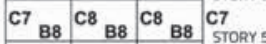

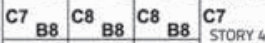

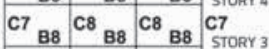

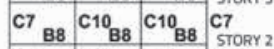

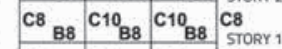

\begin{tabular}{l|l|l|l|}
\hline C8 & C11 & C11 & C8 \\
\hline
\end{tabular}

SMRF-15

Figure 1. Structural models used in this study

same for all models and amount to $2500 \mathrm{~kg} / \mathrm{m}$ and $1000 \mathrm{~kg} / \mathrm{m}$, respectively. The dead load for roof amounts to $1750 \mathrm{~kg} / \mathrm{m}$ for the 3-storey and 5-storey models, $2083 \mathrm{~kg} / \mathrm{m}$ for the 7 -storey and 10 -storey models, and $2250 \mathrm{~kg} / \mathrm{m}$ for the 15 -storey model. The roof live load of $750 \mathrm{~kg} / \mathrm{m}$ has been adopted for all models. The importance factor of residential buildings and the reduction factor have been assumed to be 1 and 10, respectively (based on Iranian code). The P- $\Delta$ effects are considered in the analysis and design of structures. Material specifications of the elements, including the module of elasticity, yield strength and Poisson's ratio, were assumed to be $E=2.1 \times 10^{6} \mathrm{~kg} / \mathrm{cm}^{2}, f_{y}=2400 \mathrm{~kg} / \mathrm{cm}^{2}$ and $v=0.3$, respectively. In addition, according to the Iranian Steel Structure Design Code (The Iranian Steel Structure Design Code features two methods ASD and LRFD for the design of steel structures and some parts of its regulations are similar to AISC-89, while others are similar to UBC-97) structural elements are designed as seismic compact elements. Girders and columns are designed by I-shapes and tube sections, respectively.

\subsection{Assumptions for the non-linear dynamic analysis}

The non-linear time history of structures was analysed using the RAMPerform-3DS software, according to the following assumptions:

- The force-displacement relationship was considered according to FEMA 356. Details of plastic hinges of brittle and ductile elements are shown in Figure 2 [26].

- The time step for the nonlinear dynamic analysis was chosen to be $0.005 \mathrm{~s}$ and, in order to control duration of the analysis, 1000 sub-steps were considered for each time step.

- Large displacements and P- $\Delta$ effects were taken into account in the non-linear dynamic analysis.

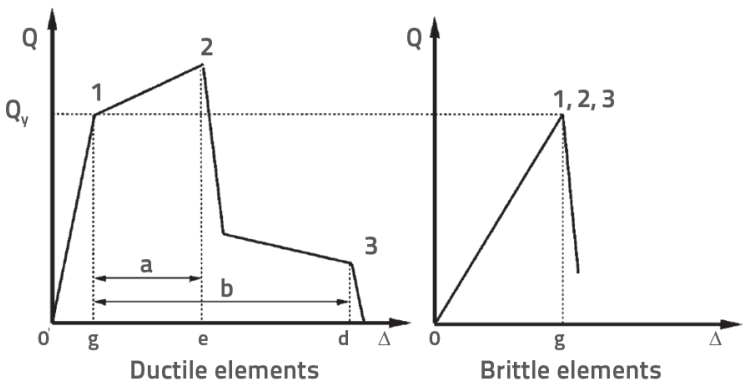

Figure 2. Behaviour curve of: a) ductile element; b) brittle element [26]

- According to the recommendation from the Iranian Seismic Code (2005), the structure damping was considered to be $5 \%$ of critical damping [25].

- A number of methods for scaling the earthquake records are provided in seismic codes for the design of new structures, or rehabilitation of the existing structures. For instance, the response spectrum of records should be equal to a certain design spectrum in a specific time range, or all record response ranges must be equal in the fundamental period of the structure. These methods are suitable for designing new structures but, in this study, the near and far field records were scaled to the same PGA for the following reasons. First, the goal of this study is to compare responses of the models to pulse-like motions and cyclic motions, and not to design or rehabilitate structures. Hence, except for directivity effects, because of lower attenuation, the PGA value is greater in the near field than in the far field of the fault. Therefore, in order to consider only pulse-like motions caused by forward directivity effects, all the records were scaled by the maximum ground acceleration of $0.35 \mathrm{~g}$. The second 
reason is that, according to the Iranian Seismic Code, an equal PGA is assumed for regions located in both the near and far field of active faults as a constant hazard level, in case of regions with a high seismic hazard.

- Based on FEMA 356 (2000) criteria [26], if seven or more consistent pairs of horizontal ground motion records are used for the time historey analysis, the use of an average of all responses of the parameter of interest shall be permitted for design. Hence, average results of maximum response of structural models were adopted for comparing parameters in the near and far field of the fault.

\section{Design demand of structural models}

Due to simplicity of calculations, the equivalent static method, which can be used for designing regular low-height buildings, is one of the common methods for estimating earthquake forces. This method is suitable for the buildings in which more than $90 \%$ of the effective mass participates in the first oscillation mode. To investigate the design demand, the mean plus standard deviation of response spectra of near and far fault records is used in this study. The spectra are presented in Figure 3 for the $5 \%$ damping value. Smoothed results of the mean plus standard deviation for near and far fault response spectra are compared in Figure 3.

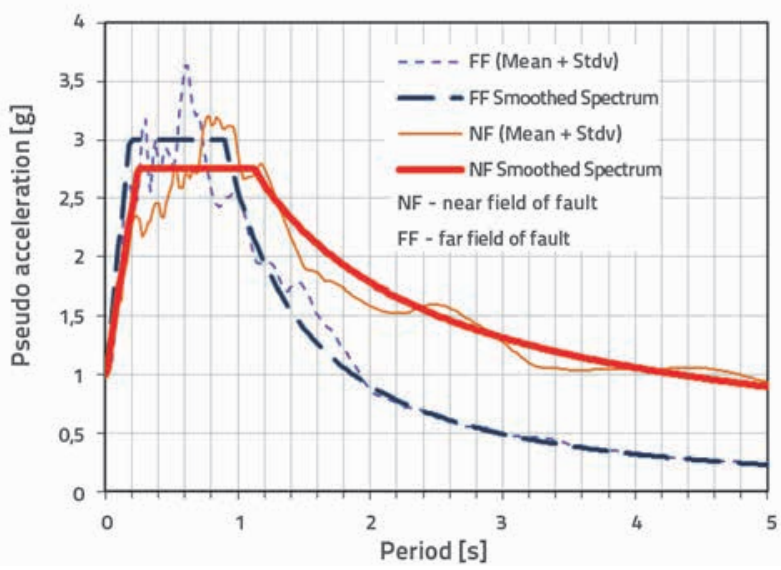

Figure 3. Smoothed response spectra for near and far field of fault, $\zeta=5 \%$

Based on Figure 3, smoothed near and far fault response spectra were obtained by considering the same area under the smoothed and main spectra curves. Results show that the nearfault smoothed spectrum at the period of 1s or higher is greater than that for the far-fault. This result is in good accordance with the near-fault design spectra of studies carried out by Saiidi and Somerville (2005), as shown in Figure 4 [24].

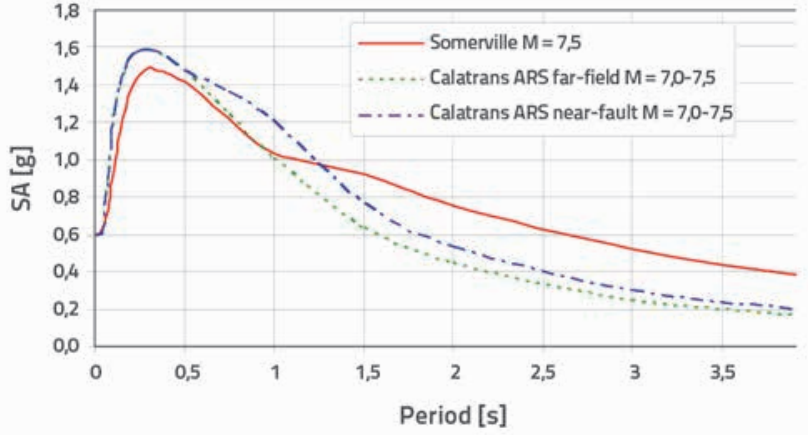

Figure 4. Comparison of acceleration response spectrum for near and far field of fault, $\zeta=5 \%[24]$

To examine the design demand of the models by means of the equivalent static procedure according to the Iranian Seismic Code, $3^{\text {th }}$ edition (2005) [25] and the smoothed spectra from Figure 3 , the base shear of each model is calculated using equations 1 and 2 .

$$
\begin{aligned}
& T=0.08 H^{\frac{3}{4}} \\
& V=\frac{A B I}{R} W
\end{aligned}
$$

Parameters used in equations 1 and 2 are: $T$ - fundamental period of structure (s); $H$ - structure height $(\mathrm{m}) ; \mathrm{V}$ - base shear; $A$ - maximum ground acceleration at the intended damage level of earthquake (in this case, it is $0.35 \mathrm{~g}$ ); $B$ - design spectrum at the fundamental period of the structure obtained from Figure 3; I, importance factor (here it is 1); $R$ - earthquake force reduction factor $(R=10) ; W$ effective weight of the structure (dead load+0.2 live load). The base shear of each model is presented in Table 2 based on the relationships from the Iranian Seismic Code, and the smoothed response spectra in the near and far field of Figure 3.

After lateral loading of the models, the ratios of available to allowable stress of each model was calculated for the near and far field of fault. The results are compared in Table 3. Results from Table 3 show that the maximum increase in the percentage of available stress to allowable stress ratio for the 7-storey and taller models in the near field of fault is by $10 \%$ to $19 \%$ higher than that of the far field of fault. For the low-rise models, the ratio of available to allowable stress in the near fault field is by about $4.5 \%$ lower than that in the far-fault regions. The above results show that it is better to use the envelope of the smoothed near and far fault response spectrum, rather than to use one of them

Table 2. Seismic parameters of models based on NF and FF response spectra and Iranian Code

\begin{tabular}{|c|c|c|c|c|c|}
\hline Structural parameters & SMRF-3 & SMRF-5 & SMRF-7 & SMRF-10 & SMRF-15 \\
\hline Period [s] (equation (1)) & 0.44 & 0.64 & 0.82 & 1.08 & 1.46 \\
\hline FF Base shear [kg] (equation (2)) & 11037 & 23225 & 24000 & 31115 & 37525 \\
\hline NF Base shear [kg] (equation (2)) & 8963 & 17811 & 30290 & 37193 & 42511 \\
\hline
\end{tabular}


Table 3. Available stress to allowable stress ratio in near (NF) and far (FF) field of fault

\begin{tabular}{|c|c|c|c|c|c|c|c|c|}
\hline \multirow{2}{*}{$\begin{array}{l}\text { वे } \\
\text { ثे } \\
\text { जे }\end{array}$} & \multicolumn{2}{|c|}{ Perimeter Columns } & \multicolumn{2}{|c|}{ Interior Columns } & \multicolumn{2}{|c|}{ Outside Girders } & \multicolumn{2}{|c|}{ Inside Girders } \\
\hline & FF & NF & FF & NF & $\mathrm{FF}$ & NF & $\mathrm{FF}$ & NF \\
\hline \multicolumn{9}{|c|}{ SMRF-15 } \\
\hline 15 & 0.77 & 0.80 & 0.58 & 0.63 & 0.72 & 0.75 & 0.83 & 0.87 \\
\hline 14 & 0.78 & 0.82 & 0.82 & 0.90 & 0.80 & 0.85 & 0.71 & 0.76 \\
\hline 13 & 0.71 & 0.75 & 0.69 & 0.76 & 0.86 & 0.91 & 0.90 & 0.96 \\
\hline 12 & 0.70 & 0.74 & 0.79 & 0.86 & 0.99 & 1.07 & 0.98 & 1.06 \\
\hline 11 & 0.72 & 0.76 & 0.80 & 0.87 & 0.99 & 1.06 & 0.90 & 0.98 \\
\hline 10 & 0.87 & 0.93 & 0.89 & 0.96 & 1.01 & 1.10 & 0.96 & 1.04 \\
\hline 9 & 0.73 & 0.78 & 0.74 & 0.80 & 0.94 & 1.02 & 0.92 & 1.01 \\
\hline 8 & 0.84 & 0.89 & 0.79 & 0.86 & 0.96 & 1.04 & 0.97 & 1.07 \\
\hline 7 & 0.89 & 0.95 & 0.91 & 0.98 & 0.98 & 1.06 & 1.00 & 1.10 \\
\hline 6 & 0.74 & 0.79 & 0.80 & 0.86 & 0.89 & 0.97 & 0.86 & 0.94 \\
\hline 5 & 0.79 & 0.84 & 0.86 & 0.92 & 0.93 & 1.01 & 0.86 & 0.94 \\
\hline 4 & 0.88 & 0.94 & 0.89 & 0.95 & 0.94 & 1.03 & 0.87 & 0.96 \\
\hline 3 & 0.89 & 0.95 & 0.87 & 0.92 & 0.92 & 1.01 & 0.89 & 0.98 \\
\hline 2 & 0.87 & 0.93 & 0.91 & 0.97 & 0.90 & 0.98 & 0.88 & 0.97 \\
\hline 1 & 0.92 & 1.00 & 0.92 & 0.98 & 0.77 & 0.85 & 0.78 & 0.85 \\
\hline \multicolumn{9}{|c|}{ SMRF-10 } \\
\hline 10 & 0.70 & 0.74 & 0.48 & 0.55 & 0.72 & 0.75 & 0.76 & 0.81 \\
\hline 9 & 0.82 & 0.90 & 0.83 & 0.95 & 0.71 & 0.78 & 0.72 & 0.78 \\
\hline 8 & 0.90 & 0.99 & 0.89 & 1.02 & 0.87 & 0.96 & 0.83 & 0.91 \\
\hline 7 & 0.80 & 0.88 & 0.84 & 0.95 & 0.78 & 0.88 & 0.85 & 0.95 \\
\hline 6 & 0.78 & 0.86 & 0.88 & 0.99 & 0.91 & 1.02 & 0.91 & 1.02 \\
\hline 5 & 0.79 & 0.88 & 0.90 & 1.02 & 1.00 & 1.14 & 0.95 & 1.07 \\
\hline 4 & 0.93 & 1.04 & 0.94 & 1.05 & 0.88 & 1.01 & 0.84 & 0.95 \\
\hline 3 & 0.91 & 1.01 & 0.79 & 0.88 & 0.87 & 0.99 & 0.90 & 1.03 \\
\hline 2 & 0.90 & 1.01 & 0.85 & 0.94 & 0.89 & 1.01 & 0.93 & 1.06 \\
\hline 1 & 0.97 & 1.10 & 1.01 & 1.13 & 0.85 & 0.96 & 0.85 & 0.96 \\
\hline \multicolumn{9}{|c|}{ SMRF-7 } \\
\hline 7 & 0.66 & 0.72 & 0.46 & 0.55 & 0.74 & 0.79 & 0.74 & 0.78 \\
\hline 6 & 0.80 & 0.90 & 0.79 & 0.94 & 0.69 & 0.77 & 0.69 & 0.76 \\
\hline 5 & 0.85 & 0.97 & 0.87 & 1.03 & 0.84 & 0.96 & 0.80 & 0.90 \\
\hline 4 & 0.83 & 0.94 & 0.78 & 0.92 & 0.79 & 0.91 & 0.80 & 0.92 \\
\hline 3 & 0.93 & 1.07 & 0.91 & 1.07 & 0.87 & 1.01 & 0.91 & 1.05 \\
\hline 2 & 0.78 & 0.89 & 0.82 & 0.96 & 0.92 & 1.07 & 0.91 & 1.05 \\
\hline 1 & 0.88 & 1.04 & 0.95 & 1.11 & 0.90 & 1.04 & 0.85 & 0.98 \\
\hline \multicolumn{9}{|c|}{ SMRF-5 } \\
\hline 5 & 0.73 & 0.69 & 0.51 & 0.43 & 0.91 & 0.87 & 0.87 & 0.83 \\
\hline 4 & 0.85 & 0.74 & 0.89 & 0.74 & 0.74 & 0.67 & 0.70 & 0.64 \\
\hline 3 & 1.03 & 0.89 & 1.04 & 0.86 & 0.95 & 0.83 & 0.88 & 0.77 \\
\hline 2 & 0.94 & 0.82 & 0.89 & 0.75 & 1.08 & 0.93 & 1.05 & 0.90 \\
\hline 1 & 1.03 & 0.86 & 1.11 & 0.93 & 1.10 & 0.95 & 1.08 & 0.93 \\
\hline \multicolumn{9}{|c|}{ SMRF-3 } \\
\hline 3 & 0.73 & 0.69 & 0.51 & 0.43 & 0.91 & 0.87 & 0.87 & 0.83 \\
\hline 2 & 0.85 & 0.74 & 0.89 & 0.74 & 0.74 & 0.67 & 0.70 & 0.64 \\
\hline 1 & 1.03 & 0.89 & 1.04 & 0.86 & 0.95 & 0.83 & 0.88 & 0.77 \\
\hline
\end{tabular}

only, in cases when new structures are designed in regions affected by the near and far source motions with the same PGA for a given hazard level.

\section{Global effects of forward directivity on structural models}

\subsection{Base shear}

Average results of base shear in the near and far field of fault were obtained by nonlinear time history analysis, in order to study forward directivity effects on base shear by varying heights of the models. In Figure 5, average base shear results are compared in the near and far field of fault for each model. Results of each model show that the difference between the base shears of the near and far field of fault increases with an increase in the model height.

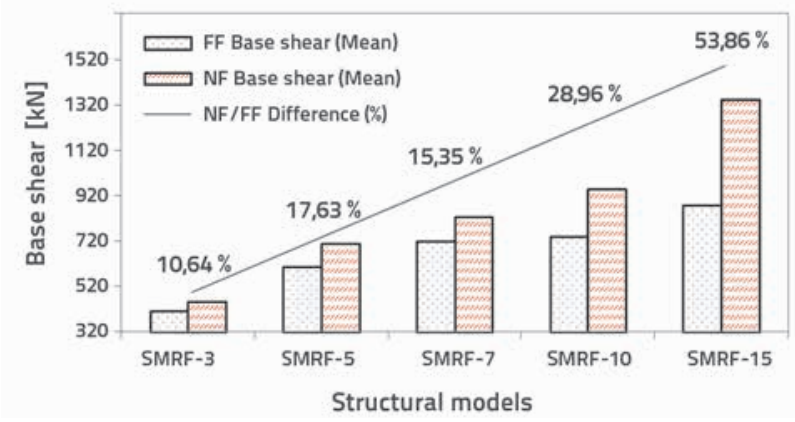

Figure 5. Comparison of average base shear results in near and far field of fault

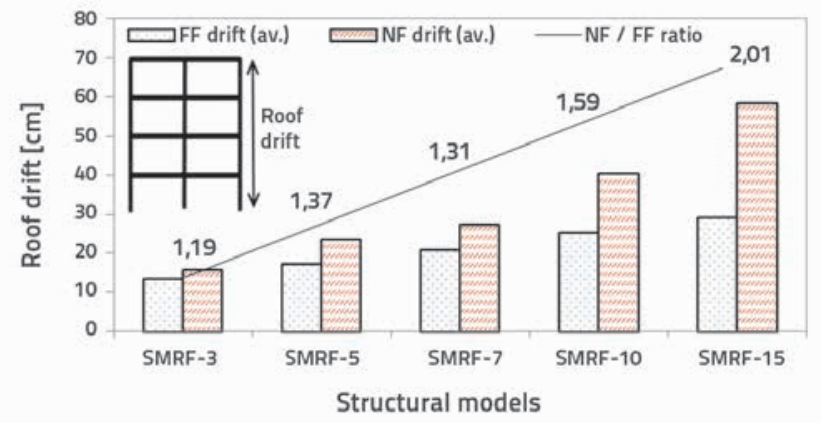

Figure 6. Comparison between average results of roof drift in near and far field of fault

\subsection{Drift}

Controlling relative displacements in structures is one of important steps in the design of structures. In this respect, the drift demand is directly related with the ductility demand of the structure. The following equation (Equation 3 ) is specified in the Iranian Seismic Design Code for the estimation of relative drift (inelastic drift) of storeys by the method of static analysis [25]:

$\Delta_{\text {ine }}=0,7 \mathrm{R} \Delta_{\mathrm{el}}$ 

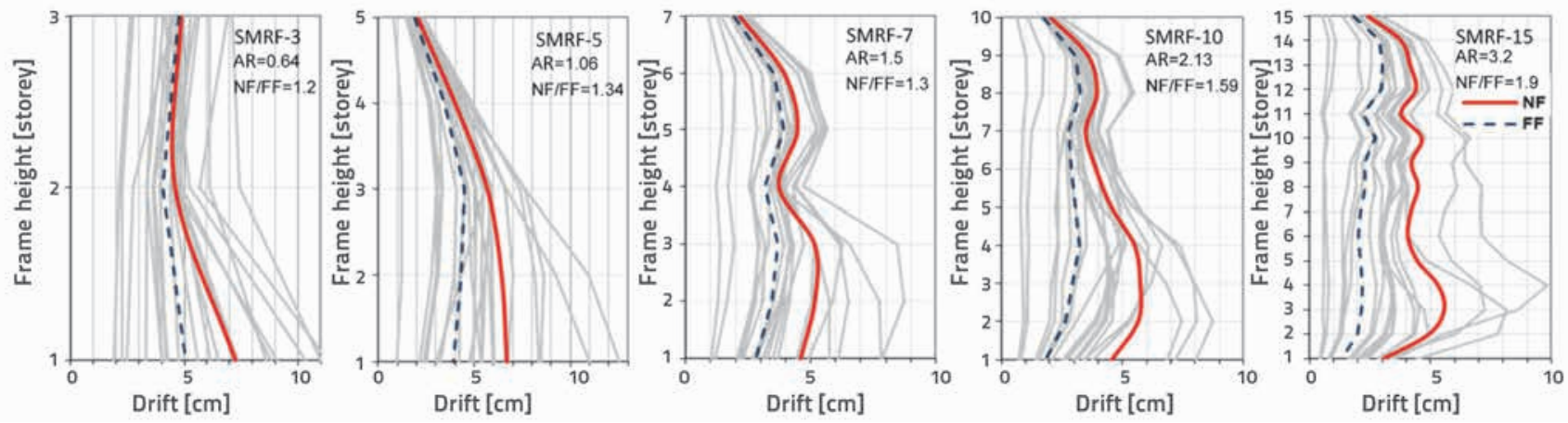

Figure 7. Comparison of mean results of storey drift demand in near (NF) and far (FF) fields of fault

where:

$\Delta_{\text {ine }}$ - the inelastic drift of storeys,

$\mathrm{R}$ - the seismic force reduction factor,

$\Delta_{\mathrm{el}}$ - the elastic drift of storeys obtained by the linear equivalent static analysis.

The Iranian seismic code (2005) limits inelastic drifts to 0.025 of the storey height for structures with periods equal to or lower than $0.7 \mathrm{~s}$, and to 0.02 of the storey height for structures with periods higher than $0.7 \mathrm{~s}$ [25]. In order to study the effect of forward directivity on drift demand, the average of roof relative displacements is investigated in Figure 6 for each of the models in the near and far field of fault. Average results show that the ratio of roof drift in near field to that of the far field of fault increases with an increase in model height. According to Figure 7, long-period pulse-like motions ( $T_{\text {pulse }}$ > $0.7 \mathrm{~s}$ ) in near-fault regions lead to the increase in storey drift, which is by about 1.1 to 2.6 times greater compared to the far-field of fault. Average storey drift results show that the maximum drift demand occurs in the lower half of the models. These results correspond well with the studies of Sehhati el al. (2011) [10].

\section{Local effects of forward directivity on structural models}

\subsection{Nodal rotations under the effect of forward directivity}

Assuming that the joints between girders and columns are rigid, the rotation of nodes can be approximately considered as a criterion for evaluating the ductility demand of structural elements. In Figure 8, the effects of forward directivity on the rotation of nodes over the height of the structure are studied by comparing results in the near and far field of fault.

According to Figure 8, nodal rotations at the top of the models are very close for the near and far field of fault. However, for the lower parts of the models, the rotations of nodes in the near field of fault are between 1.2 to 3.5 times greater than the corresponding values of the far-fault regions. In the near field of fault, most nodal rotations are concentrated in the lower half of the models, and the difference between average results of near and far field of fault clearly increases with an increase in height. The comparison of Figures 8-a and 8-b shows that the perimeter nodes rotate 1.05 to 2 times more than the corresponding interior nodes, except for the nodes located at the highest storey. The perimeter nodes of the highest storey rotate 2 to 2.5 times more than the interior nodes. Results show that in the near field of fault, the vulnerability is significant for the perimeter structural elements that are located in the lower half of the structure.

\subsection{Forward directivity effects on columns}

\subsubsection{Relationship between aspect ratio and forward directivity effects on columns}

To show in a simple way an approximate relationship of the building aspect ratio and the forward directivity effect on the increase of column axial forces, as shown in Figure 9, three one-degree-of-freedom moment frames with equal lateral stiffness, and with the same gravitational and lateral loads, were considered at different aspect ratios of (h/b), 0.5, 1 and 2 . Then, the values of bending moment and columns axial forces were computed according to Equations 4 and 5 by using the Slope-Deflection method [29] and the equilibrium relationship of $\sum M_{a}=0$. In addition, the axial deformation of columns and the $\mathrm{P}-\Delta$ effect were not considered in Equations 4 and 5 for models shown in Figure 9.

$M_{a}=M_{b}=\frac{P h}{4}$
$F_{b y}=\frac{P}{2}\left(\frac{h}{b}\right)+\frac{W}{2}$

where:

$M$ - the columns bending moment,

$F$ - the column axial force,

$P$ - the earthquake lateral load,

$W$ - the ceiling weight,

$h$ - the frame height,

$b$ - the frame width. 
a) Perimetar nodes
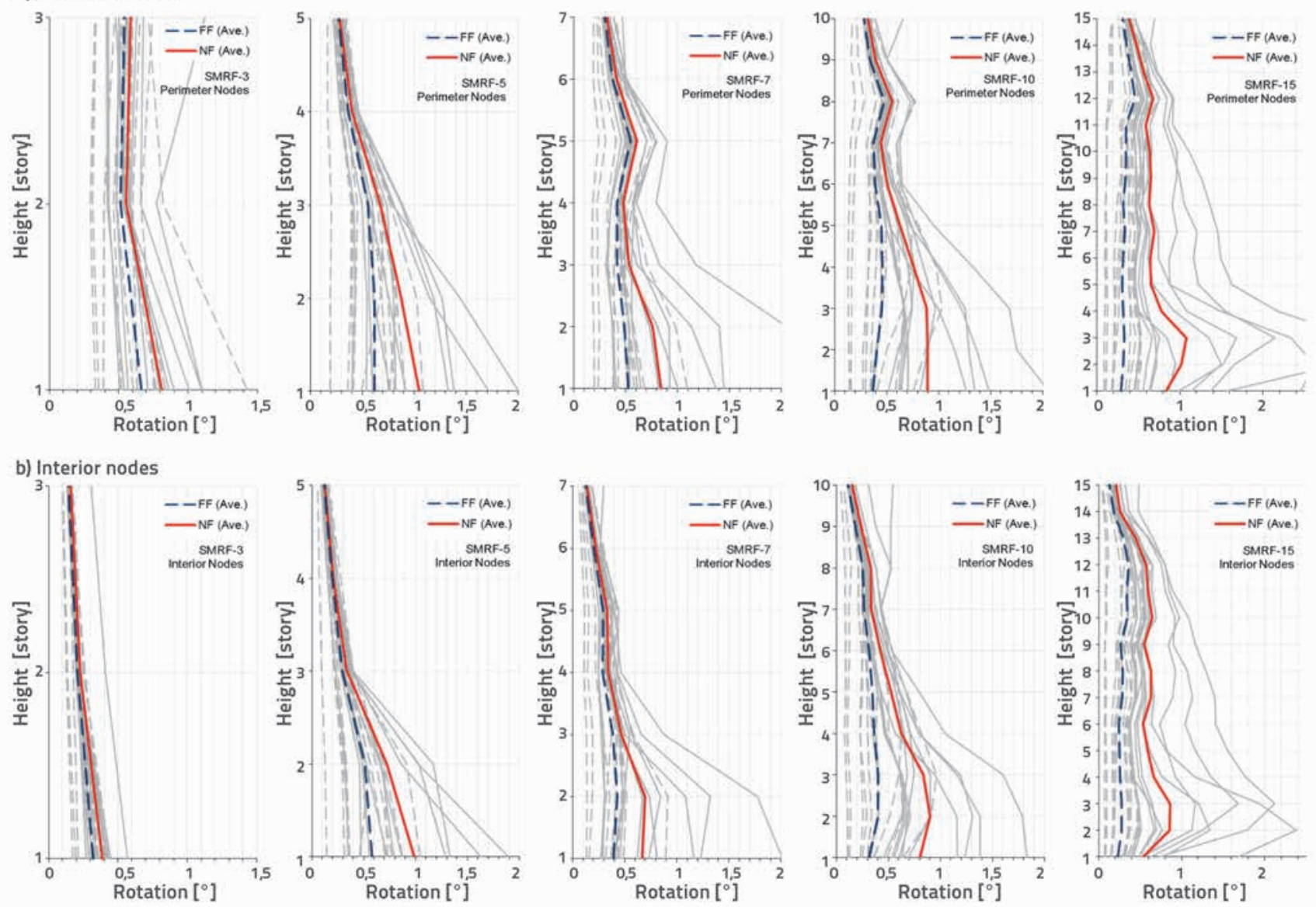

Figure 8. Average results of nodal rotation in near and far field of fault

As can be seen from Figure 9, the change of the aspect ratio has no effect on the columns bending moment, but it is directly related to the columns axial force; thus, one unit change in the aspect ratio ( $h / b$ ) changes the columns axial force for $(P / 2)$. In order to determine the relationship between the aspect ratio on one hand, and the forward directivity effect on the columns axial force on the other hand, the equation 5 was rewritten with and without the forward directivity effect. The equation (6) shows the column axial force without considering the forward directivity effect, and the equation (7) illustrates the column axial force while taking into account the forward directivity effect. By subtracting the equation (6) from the equation (7), the relationship between the aspect ratio and the forward directivity effect on the columns axial force is obtained, as shown in equation (8).

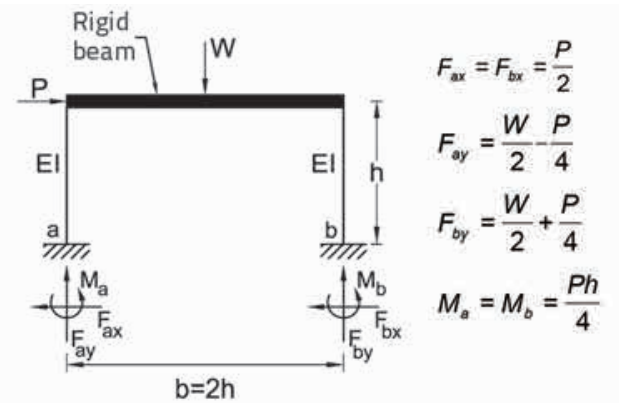

Aspect Ratio $=0,5$

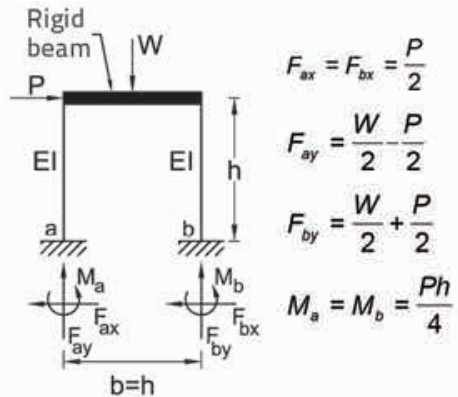

Aspect Ratio $=1$

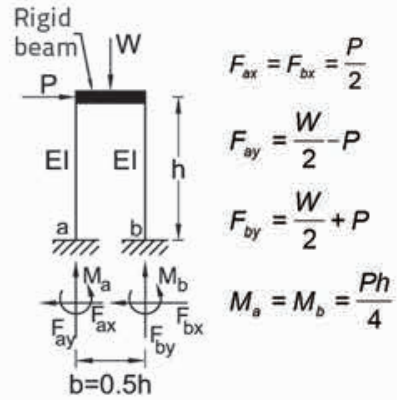

Aspect Ratio $=2$

Figure 9. Comparison of variations of frame columns axial force and bending moment of one-degree-of-freedom systems with respect to aspect ratio variations 
$F_{b y(N D)}=\frac{P_{N D}}{2}\left(\frac{h}{b}\right)+\frac{W}{2}$

$F_{b y(F D)}=\frac{\left(P_{N D}+\Delta P_{F D}\right)}{2}\left(\frac{h}{b}\right)+\frac{W}{2}$

$\Delta P_{F D}=F_{b y(F D)}-F_{b y(N D)}=\frac{\left(P_{N D}+\Delta P_{F D}\right)}{2}\left(\frac{h}{b}\right)+\frac{W}{2}-\frac{P_{N D}}{2}\left(\frac{h}{b}\right)-\frac{W}{2}=\frac{\Delta P_{F D}}{2}\left(\frac{h}{b}\right)$

where:

$F_{\text {by(ND) }}$ - the column axial force in the regions with neutral directivity feature (without the forward directivity effect),

$F_{b y(F D)}$ - the column axial force considering forward directivity effects,

$P_{N D} \quad$ - the lateral force without forward directivity effect,

$\triangle P_{F D}$ - the amount of lateral force variations arising from the forward directivity effect,

$\Delta F_{F D}$ - the amount of column axial force variations arising from the forward directivity effect.

The equation (8) shows that there is a direct relationship between the aspect ratio ( $h / b$ ) and the columns axial force variations arising from the forward directivity effect; thus, by one unit increase in the aspect ratio, the forward directivity effect increases the axial force by $\Delta P_{F D} / 2$, which is a half of the forward directivity effect in the storey shear.

\subsubsection{Forward directivity effect on column demands}

In order to investigate the forward directivity effect on the internal forces of perimeter (external) and interior (internal) columns, the average percentage of increase in columns axial forces in near fault field is plotted in Figure 10 using the non-linear dynamic analysis. According to Figure 10, in the models with less than 10 storeys, the axial forces of perimeter columns increase by about $2.7 \%$ to $9.47 \%$, while the increase percentage of axial forces of internal columns decreases by $0.57 \%$. It can also be seen that, for the 15 -storey model, the forward directivity has increased the axial forces by about $13.77 \%$ for perimeter columns, and by $7.5 \%$ for interior columns.

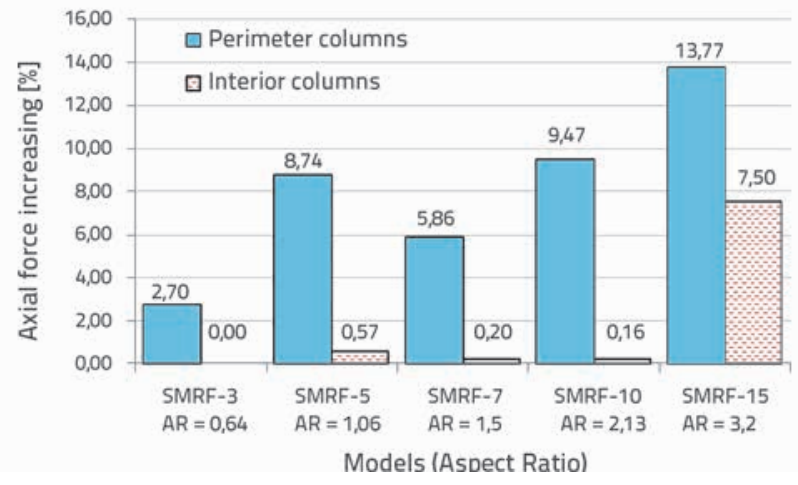

Figure 10. Average increase percentage of axial forces for perimeter and interior columns due to forward directivity effects

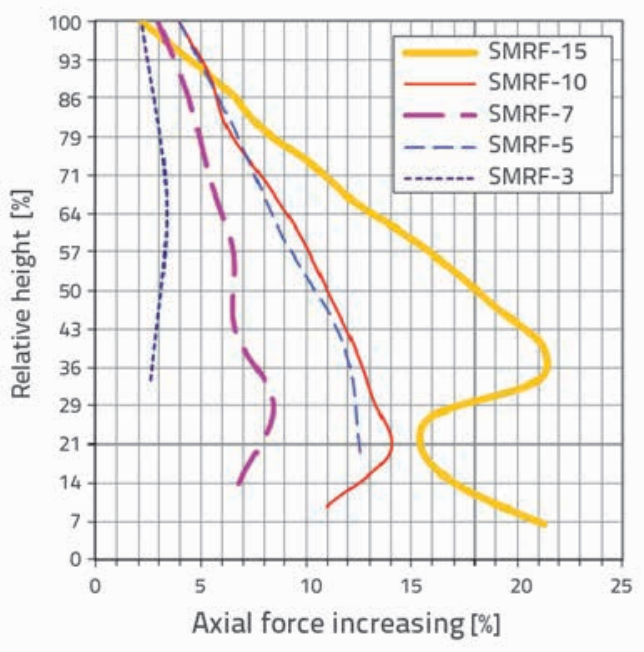

Figure 11. Average percentage of increase in axial forces for perimeter columns of modelled storeys

Figure 11 shows an average percentage of increase in axial force for perimeter columns under the forward directivity effect at the relative height of structural models. According to Figure 11, the forward directivity effect increases the axial force of perimeter columns by about $3 \%$ to $15 \%$ for low and middle-rise frames ( 3 to 10 -storey models). For the high-rise models, the forward directivity effect increases the axial force of perimeter columns by about $15 \%$ and $23 \%$ in the lower 50 $\%$ of the structure height. The results show that an increase in the aspect ratio causes an increase in the forward directivity effect on the axial force of perimeter columns. It can be seen that an increase in the aspect ratio of about 2 times, leads to a 2.2 times increase in the effect of forward directivity on axial force of perimeter columns.

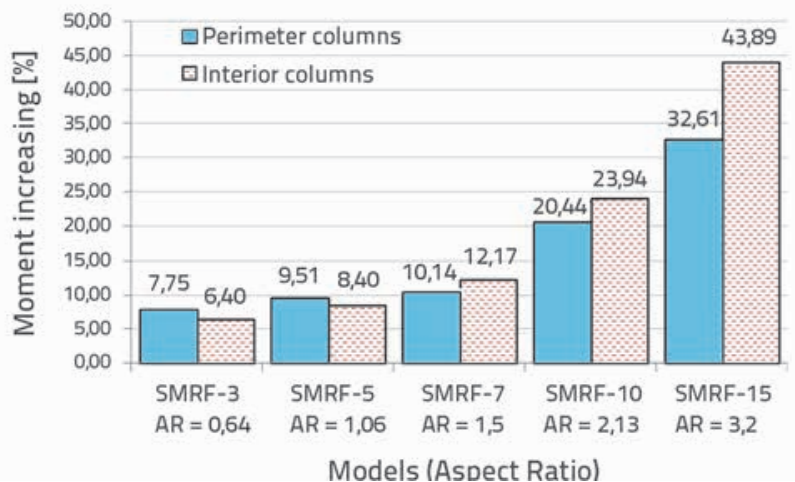

Figure 12. Percentage of increase in bending moments of columns in near field of fault

An average percentage of increase in the maximum bending moment of columns is investigated in Figure 12. Results show that average bending moment values of columns in the near field of fault are by about $6.4 \%$ to $9.51 \%$ greater than those in the far fault in case of low and middle-rise models (7-storey and less). In 
addition to that, perimeter columns results are very close to interior columns results, with a difference of less than $1.5 \%$. For high-rise models (10-storey and more), an increase in the height leads to an increase in the percentage difference between bending moments of internal and external columns, so that in the 15-storey model the forward directivity increases the bending moment of the columns by about $32.61 \%$ to $43.89 \%$. As can be seen from Figure 13 , the values of increase in the bending moment of models with less than 7 storeys are very close to one another, so that the effect of forward directivity increases the columns bending moment by about $10 \%$ and $20 \%$ for external (perimeter) columns, and $4 \%$ and $16 \%$ for internal columns. As the height increases, the percentage of the columns bending moment also increases, so that an average percentage of increase in bending moment is about $30 \%$ to $50 \%$ for the 10 -storey model, and about $40 \%$ to $56 \%$ for the 15 -storey model. Results given in Figure 13 show that an average percentage of increase in bending moment for interior columns is by about $3 \%$ to $12 \%$ higher than that of external columns, and that most part of the percentage of increase in the bending moment arising from the forward directivity in the first and the second floors of high-rise models occurs at perimeter columns.
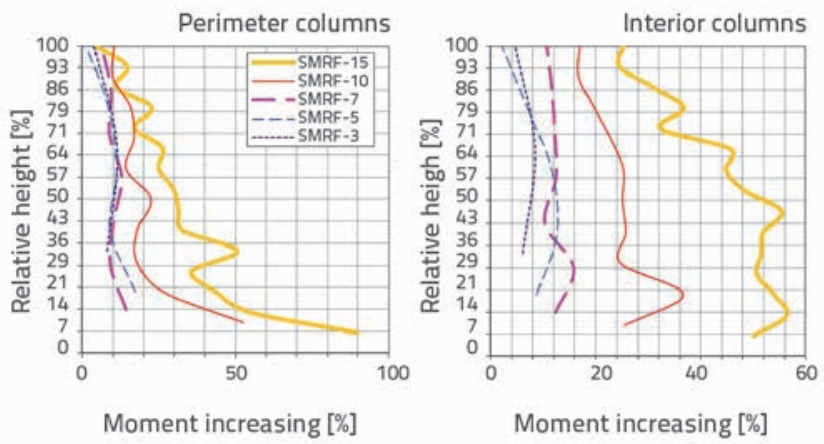

Figure 13. Average percentage of increase in bending moments of perimeter and interior columns

\subsubsection{Forward directivity effects on columns capacity}

Columns of the steel moment resisting frames are subjected to combined effects of the bending moment and axial forces. Therefore, the interaction curve of axial force and bending moment is considered in the design of the columns. In other words, an increase in the amount of axial force decreases the values of strength and ductility of bending moment for columns. Since the forward directivity effect increases the axial force in the columns, the capacity of strength and ductility of the columns was studied to determine dependence of bending on the variation of axial forces.

\section{Bending strength capacity of columns}

In this study, the FEMA 356 criteria are considered to determine the strength capacity of columns. Based on FEMA 356 [26], columns subjected to compression forces are forcecontrol elements. Equations (9) to (11) are provided by FEMA 356 for evaluating the columns under the combined axial force and bending moment by means of linear-analysis methods.

For $\frac{P_{U F}}{P_{C L}}<0,2$

$\frac{P_{U F}}{2 P_{C L}}+\frac{M_{x}}{m_{x} M_{C E x}}+\frac{M_{y}}{m_{y} M_{C E y}} \leq 1,0$

For $0,2 " \frac{P_{U F}}{P_{C L}} 0,5$ :

$\frac{P_{U F}}{P_{C L}}+\frac{8}{9}\left(\frac{M_{x}}{m_{x} M_{C E x}}+\frac{M_{y}}{m_{y} M_{C E y}}\right) \leq 1.0$

For $\frac{P_{U F}}{P_{C L}}>0,5$ :

$\frac{P_{U F}}{P_{C L}}+\frac{M_{U F x}}{M_{C L x}}+\frac{M_{U F y}}{M_{C L y}} \leq 1,0$

where:

$P_{U F} \quad-$ the column axial force,

$P_{C L} \quad$ - the lower-bound compression strength of the column,

$M_{x} \& M_{y} \quad$ - bending moments about x and y axes, respectively, $M_{C E x} \& M_{C E y}$ - expected bending strengths about $x$ and $y$ axes,

$M_{C L X} \& M_{C L y}$ - lower-bound flexural strength of the members about the $x$ and $y$ axes,

$m_{x} \& m_{y} \quad$ - bending capacity increase coefficients which are variable depending on the value of $P_{U F} / P_{C L^{\prime}}$ intended performance level and type of structural section (slenderness or non-slenderness). The values of $m$ coefficients are presented in Table 4.

Assuming the life safety performance level, one-directional bending $\left(M_{y}=M u_{F y}=0\right)$, and $M_{C E}=1.1 M_{C L^{\prime}}$ scaled interaction curves of axial force and bending moment have been considered for studying variation of bending strength of

Table 4. $\mathrm{m}$-factor presented by FEMA356 in life safety performance level* [26]

\begin{tabular}{|c|c|c|c|}
\hline \multicolumn{2}{|c|}{$\mathrm{P} / \mathrm{P}_{\mathrm{CL}}<0.2$} & \multicolumn{2}{|c|}{$0.2<P / P_{C L}<0.5$} \\
\hline $\begin{array}{c}\text { Case a: } \\
\frac{b_{f}}{2 t_{f}} \leq \frac{52}{\sqrt{F_{y e}}} \& \frac{h}{t_{W}} \leq \frac{300}{\sqrt{F_{y e}}}\end{array}$ & $\begin{array}{c}\text { Case b: } \\
\frac{b_{f}}{2 t_{f}} \leq \frac{65}{\sqrt{F_{y e}}} \text { or } \frac{h}{t_{W}} \leq \frac{460}{\sqrt{F_{y e}}}\end{array}$ & $\begin{array}{c}\text { Case a: } \\
\frac{b_{f}}{2 t_{f}} \leq \frac{52}{\sqrt{F_{y e}}} \& \frac{h}{t_{w}} \leq \frac{260}{\sqrt{F_{y e}}}\end{array}$ & $\begin{array}{c}\text { Case b: } \\
\frac{b_{f}}{2 t_{f}} \leq \frac{65}{\sqrt{F_{y e}}} \text { or } \frac{h}{t_{W}} \leq \frac{400}{\sqrt{F_{y e}}}\end{array}$ \\
\hline 6 & 1.25 & $9\left(1-1.7 \mathrm{P} / \mathrm{P}_{\mathrm{CL}}\right)$ & 1.25 \\
\hline
\end{tabular}


columns with respect to the variation of axial force. Figures 14.a and 14.b show scaled axial-bending force interaction curves for non-slender and slender wall sections, which are obtained from equations (9) to (11). In addition, according to FEMA 356 criteria and based on equations (9) to (10), the percentage of variation in the columns bending capacity versus axial force changes is shown in Figure 15 . The comparison of Figure 14-a with Figure 14-b shows that the column bending capacity is reduced by about 0.2 to 0.7 times of that in structural elements with non-slender wall sections, in case structural elements with slender wall section are used.
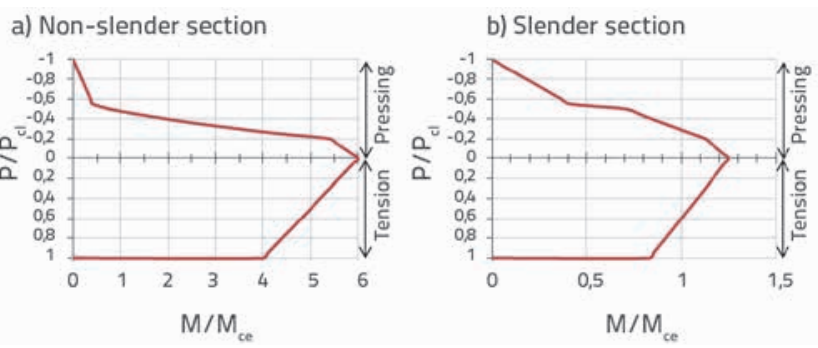

Figure 14. Scaled interaction diagram of axial force and bending moment in columns

According to Figures 14 and 15, if the values of axial force are increased by about $30 \%$ of $P_{C_{L}}$ (lower-bound axial columns capacity) this will lead to the reduction of bending moment capacity of columns by about $30 \%$ to $80 \%$. Therefore, according to Figures 10 and 11, a $5 \%$ to $20 \%$ increase in the axial force caused by forward directivity can reduce the column bending capacity by about $12.5 \%$ to $50 \%$. On the other hand, according to Figures 12 and 13, the forward directivity increases the bending moment of columns by about $10 \%$ to $56 \%$ which can seriously damage columns, especially at lower storeys.

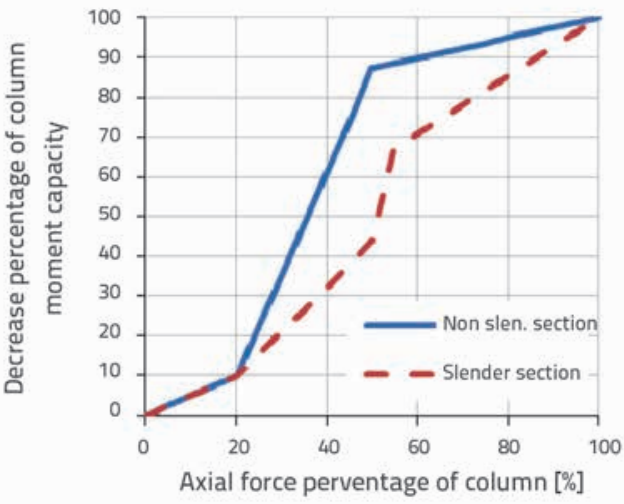

Figure 15 . Variation of bending capacity vs. axial force

\section{Bending ductility capacity of columns}

According to FEMA 356, structural elements are categorized into three groups: brittle (non-ductile), semi-ductile, and ductile. Non-ductile elements are force-controlled and ductile elements are deformation-controlled. Depending on the axial compression force value, the bending behaviour of steel columns can be either force-controlled or deformationcontrolled. For steel columns under combined axial compression and bending stress, when the axial compression force is lower than $50 \%$ of $P_{C L}$ (axial lower-bound of column capacity), the column bending behaviour is deformationcontrolled. If the axial force is higher than $50 \%$ of $P_{C L}$ then the bending behaviour of column will be force-controlled. FEMA 356 has provided some values of maximum bending deformation of columns for different performance levels and different ratios of $P_{U F} / P_{C L}$ and for columns with slender and non-slender wall sections (Table 5). In order to study the variation of bending ductility with respect to the variation of

Table 5. Modeling parameters and maximum allowed plastic rotation of columns ${ }^{1}[26]$

\begin{tabular}{|c|c|c|c|c|c|c|c|}
\hline \multicolumn{2}{|r|}{ Component/Action } & \multicolumn{3}{|c|}{ Modeling parameters } & \multicolumn{3}{|c|}{ Plastic rotation angle (Radian) } \\
\hline & & $\mathrm{a}$ & $\mathrm{b}$ & c & 10 & LS & $\mathrm{CP}$ \\
\hline \multicolumn{8}{|c|}{ Columns-flexure, for $\mathrm{P} / \mathrm{P}_{\mathrm{cL}}<0.2$} \\
\hline a. & $\frac{b_{f}}{2 t_{f}} \leq \frac{52}{\sqrt{F_{y e}}} \& \frac{h}{t_{w}} \leq \frac{300}{\sqrt{F_{y e}}}$ & $9 \theta_{y}$ & $11 \theta_{y}$ & 0,6 & $1 \theta_{\mathrm{y}}$ & $6 \theta_{y}$ & $8 \theta_{y}$ \\
\hline b. & $\frac{b_{f}}{2 t_{f}} \geq \frac{65}{\sqrt{F_{y e}}}$ or $\frac{h}{t_{w}} \geq \frac{460}{\sqrt{F_{y e}}}$ & $4 \theta_{y}$ & $6 \theta_{y}$ & 0,2 & $0,25 \theta_{y}$ & $2 \theta_{y}$ & $3 \theta_{y}$ \\
\hline \multicolumn{8}{|c|}{ Columns-flexure, for a $0.2<\mathrm{P} / \mathrm{P}_{\mathrm{CL}}<0.5$} \\
\hline a. & $\frac{b_{f}}{2 t_{f}} \leq \frac{52}{\sqrt{F_{y e}}} \& \frac{h}{t_{w}} \leq \frac{260}{\sqrt{F_{y e}}}$ & $---^{2}$ & $---^{3}$ & 0,2 & $0,25 \theta_{y}$ & $---^{4}$ & $---^{2}$ \\
\hline b. & $\frac{b_{f}}{2 t_{f}} \geq \frac{65}{\sqrt{F_{y e}}}$ or $\frac{h}{t_{w}} \geq \frac{400}{\sqrt{F_{y e}}}$ & $1 \theta_{y}$ & $1,5 \theta_{y}$ & 0,2 & $0,25 \theta_{y}$ & $0.5 \theta_{y}$ & $0.8 \theta_{y}$ \\
\hline \multicolumn{8}{|c|}{$\begin{array}{l}\text { 1. Linear interpolation between the values on Items } a \text { and } b \text { for both flange slenderness (first term) and web slenderness (second term) shal } \\
\text { be performed, and the lowest resulting value shall be used. } 2 \text {. Plastic rotation }=11\left(1-1.7 P / P_{C L}\right) \theta_{y^{\prime}} 3 \text {. Plastic rotation }=17\left(1-1.7 P / P_{C L}\right) \theta_{y^{\prime}} 4 \\
\text { Plastic rotation }=8\left(1-1.7 P / P_{C L}\right) \theta_{y}\end{array}$} \\
\hline
\end{tabular}


axial force in the columns according to Table 5 and Figure 2 , the scaled force-deformation diagrams of columns are plotted in Figures 16 and 17 for slender and non-slender wall sections. Figures 16 and 17 demonstrate the relationship between ratio of $M / M_{y}$ and ratio of $\theta / \theta_{y}$ for columns in which $P / P_{C L}<0.2$ and $0.2<P / P_{C L}^{y}<0.5$. In addition, the bending ductility capacity of columns is obtained from equation (12). The corresponding results are presented in figures 16 and 17.

$\mu=\frac{\theta_{\max }}{\theta_{\text {yield }}}$

The parameters in equation (12) and Figures 16 or 17 are $M$ - bending moment; $M_{y}$ - bending moment at yield point; $\theta$ columns rotation; $\theta_{y}$ - columns rotation at yield point; $\theta_{\text {max }}-$ maximum rotation of column without strength reduction, and $\mu$ is ductility. In Figures 16 and $17 Q / Q_{y}$ is equal to $M / M_{y}$.
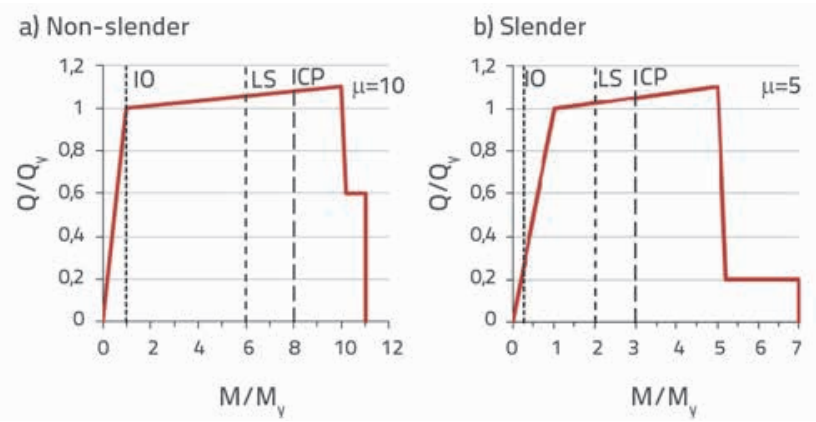

Figure 16. Ratio of $M / M_{y}$ versus ratio of $\theta / \theta_{y}$ for columns in which $P / P_{C L}<0.2$
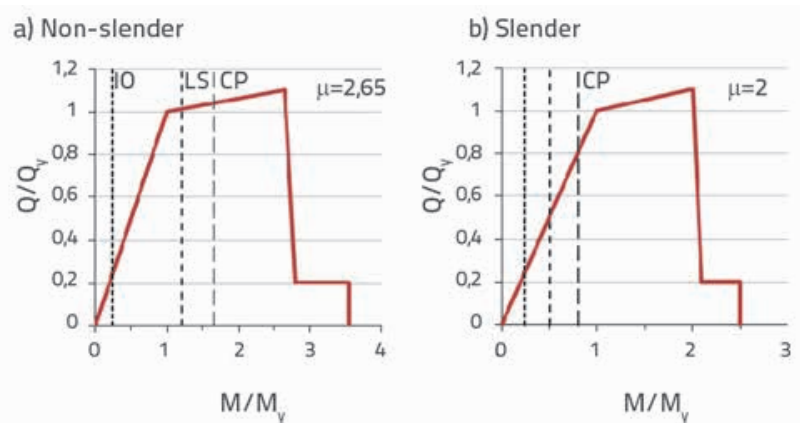

Figure 17. Ratio of $M / M_{y}$ versus ratio of $\theta / \theta_{y}$ for columns in which $0.2<P / P_{C L}<0.5$

It can be observed from Figures 16 and 17 that the columns ductility in bending can be reduced by about $25 \%$ to $50 \%$ if structural sections with slender elements are used. Moreover, the comparison of Figures 16 and 17 shows that an increase in the column axial force leads to a decrease in the column bending ductility (Figure 18) in such a way that depending on the type of structural section (slender or non-slender wall), a $30 \%$ increase in the axial force can reduce the columns bending ductility by $60 \%$ to $73.5 \%$. On the other hand, the investigation of nodes rotation at the structure height shows that the forward directivity increases the nodal rotations by about 1.1 to 1.7 times for low-rise models and by 1.4 to 3.5 times for high-rise models (Figures 8.a and 8.b). Therefore, the results indicate that the forward directivity has two major effects on columns. Firstly, depending on the aspect ratio, the forward directivity increases the axial force and bending moment of columns by about $5 \%$ to $20 \%$ and $10 \%$ to $56 \%$, respectively. Secondly, depending on the column situation and structure aspect ratio, the forward directivity decreases the bending strength and bending ductility capacities of columns by about $12.5 \%$ to $50 \%$, and $25 \%$ to $50 \%$, respectively. According to these results, the use of seismic compact sections and the minimum ratio of $P_{U F} / P_{C L}$ (conservative range is $P_{U F} / P_{C L} \leq 0.2$ ) is recommended in the design of columns, especially at the lower storeys, in the case of seismic design of steel moment resisting frames subjected to the effect of forward directivity in near field of fault. This recommendation results in a higher ductility capacity of columns, without reduction of strength. It can be seen that there are some parameters whose effects have not been considered in this study, which is due to simplifications made in the analysis of models. These parameters are the columns deformation in the other direction of the structure, the vertical component of earthquake vibration, and the effect of bracing system on axial force of columns in the other direction of the structure. These parameters can have significant effects on the strength and ductility capacity of columns (especially in case of corner columns). Therefore, these parameters should be taken into account in the design of structures on real-life projects.

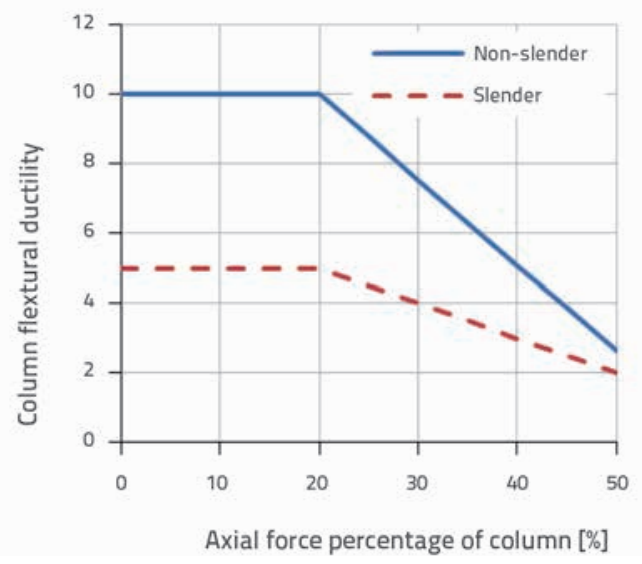

Figure 18. Variation of bending ductility capacity with respect to axial force changes

\subsection{Forward directivity effects on girders}

According to the seismic design concept of steel moment resisting frames, the plastic hinges formed by structure deformations during earthquake must occur in girders. Therefore, girders play an important role in the dissipation of earthquake energy in steel moment resisting frames. Since the bending moment is more determinative than shear force in the design of long girders, maximum bending moments of inside and outside girders were determined, in the analysis of the forward directivity effect on girders, using the nonlinear dynamic analysis in the near and far field of fault. Then 
average results of near and far field of fault were plotted with respect to the relative height of models for inside and outside girders, as shown in Figure 19.
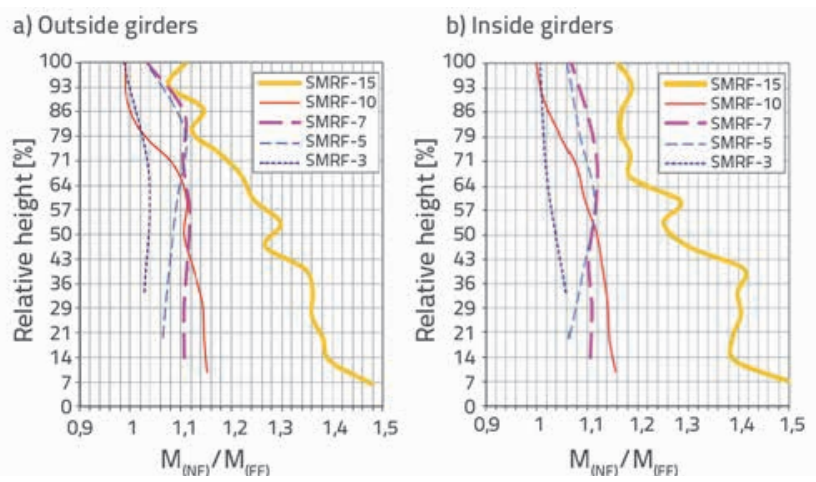

Figure 19. Ratio of maximum bending moment in near and far field of fault

Results from Figure 19 show that the forward directivity effect increases the bending moment of girders by about $2 \%$ to 16 $\%$ for models with 10 or less storeys, while in the 15 -storey model it increases the bending moment by about $10 \%$ to $50 \%$. This shows that as the height increases, the forward directivity effect increases severely (about 3 to 5 times) for the high-rise moment frames. It was established by analyzing FEMA 356 relationships relating to the strength and ductility capacity of girders that the bending strength and ductility capacities of girders are dependent on material properties and geometrical parameters of the cross-section. Hence, the forward directivity has no effect on girder capacity.

\subsection{Effect of forward directivity on the demand to capacity ratio of structural elements}

To investigate performance of structural elements at lifesafety performance level, the demand to capacity ratios (DCR) of girders and columns forming the structure were computed in the near and far field of fault according to FEMA 356 criteria.
The average ratio of near fault results to the far fault results over the relative height of structures is presented in Figure 20. Results given in Figure 20 show that the forward directivity increases the demand to capacity ratio of structural elements by about 1.1 to 1.75 times for low and middle-rise models (less than 7 storeys), while the DCR values of high-rise models increase by about 1.5 to 5 times. The results also show that in case of low and middle-rise models (7 storeys and less), the demand to capacity ratio of both the girders and the columns increase by about 1.1 to 1.75 times under the forward directivity effect at the structure height. In case of high-rise models, the DCR values of columns are affected by forward directivity by about $35 \%$ to $70 \%$ more when compared to girders. As can be seen from Figure 20, the forward directivity increases the demand to capacity ratio of columns by about 1.5 to 5 times, and the demand to capacity ratio of girders by about 1.5 to 3.2 times. Results show that the structure aspect ratio has a significant influence on the intensification of forward directivity effects on columns (especially with regard to perimeter columns).

The comparison of results of available stress to allowable stress ratio, and demand to capacity ratio of structural elements over the models height, as presented in Table 3 and Figure 20, shows that the static method leads to huge errors in the evaluation of vulnerability of structures in the near field of fault.

\section{Conclusions}

In this study, the effect of forward directivity on the local and global demand and capacity of steel moment resisting frames is studied by means of non-linear dynamic analysis of five samples of structural models. Structural models are $3,5,7,10$ and 15-storey steel moment resisting frames that are analyzed under 20 strong motion records in the near and far field of fault by nonlinear time history analysis, based on FEMA 356 provisions. Assuming equal hazard level in the near and far field of fault, and rigid connections between beams
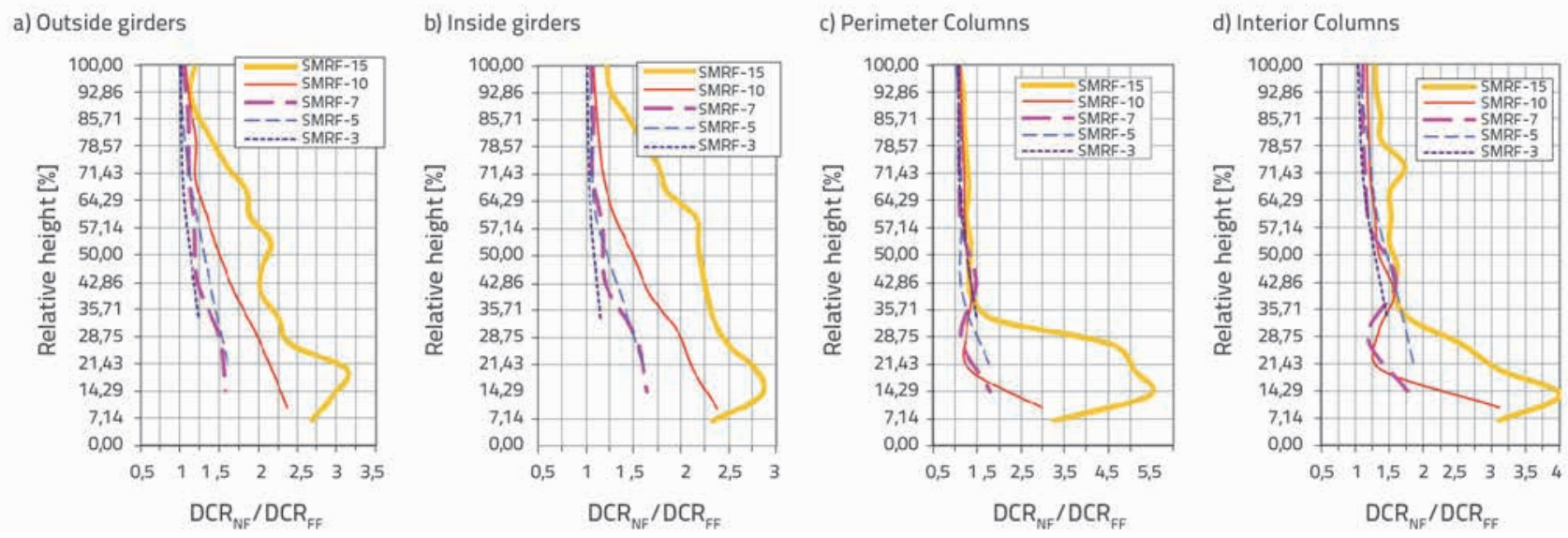

Figure 20. Ratio of near to far fault DCRs for structural elements over models height 
and columns, the study of the effects of forward directivity on design demands, base shear, drift and demand and capacity of structural elements, has led to the following conclusions:

- Aspect ratios of moment frames are directly related to the columns axial force under effect of forward directivity (especially for perimeter columns of high-rise frames). Thus, a one-unit increase in the aspect ratio increases the effect of forward directivity on axial force of columns by about $50 \%$. It was also observed that a two-time increase of the aspect ratio increases severity of the forward directivity effect on the demand to capacity ratio of structural elements by about 3 to 5 times.

- Long-period pulse-like motions ( $T_{\text {pulse }}>0.7 \mathrm{~s}$ ) caused by forward directivity exert two major effects on columns in steel moment resisting frames. Firstly, depending on the structure aspect ratio, they increase the axial force and bending moment of columns by about $5 \%$ to $20 \%$, and 10 $\%$ to $56 \%$, respectively. Secondly, depending on the location of the column and structure aspect ratio, they decrease the bending strength and bending ductility capacities of columns by about $12.5 \%$ to $50 \%$, and $25 \%$ to $50 \%$, respectively. Therefore, the demand increase and columns capacity reduction result in the increase of the demand to capacity ratio of columns by about 1.5 to 5 times in the direction normal to the fault line, which causes severe damage to columns, especially to perimeter columns located at the lower part of high-rise models.

- The study of girders demand shows that the forward directivity effect increases the bending demand of beams by about $2 \%$ to $50 \%$ and, assuming that girders are not affected by axial force, the forward directivity has no effect on the strength and ductility capacities of girders.

- For the purposes of seismic design of moment frames positioned normal to the fault line in near-fault regions, the following provision contained in seismic codes: "making use of high ductile structural elements with high flexibility for seismic resistant design of structures by means of using seismic compact sections, and design of columns with the minimum ratio of available axial force to lower-bound compression strength of less than 0.5 (the conservative range is $\left.P_{U F} / P_{C L} \leq 0.2\right)$ " is verified in this study, especially in the lower part of the high-rise moment resisting frames (especially for perimeter columns).

- In case of a constant level of hazard, when a construction site is under the effect of two seismic sources having the same ability of creating PGA at the near and far field of fault, a special envelope of smoothed near and far fault design spectrum should be used for the seismic design of structures.

\section{REFRENECES}

[1] Gioncu, V.: Framed structures Ductility and seismic response, General Report. Journal of Constructional Steel Research. 55, 125-154, 2000.

[2] Stewart, J.P., Chiou, S.J., Bray, J.D., Graves, R.W., Somerville, P.G., Abrahamson, N.A.: Ground Motion Evaluation Procedures for Performance-Based Design. Research report conducted under grant no. EEC-9701568 from the National Science Foundation, University of California, Berkeley, CA, 2001.

[3] Alavi, B., Krawinkler, H.: Effects of near-fault ground motions on frame structures. Report No. 138, The John A. Blume Earthquake Engineering Center, Stanford University, California, 2001.

[4] Alavi, B., Krawinkler, H.: Behaviour of moment-resisting frame structures subjected to near-fault ground motions. Journal of Earthquake Engineering and Structure Dynamics. 33, 678-706, 2004., DOI: 10.1002/eqe.369

[5] Bolt, B.A.: Seismic input motions for nonlinear structural analysis. Journal of Earthquake Technology. 448, 223-232, 2004

[6] Bray, J.D., Rodriguez-Marek, A.: Characterization of forwarddirectivity ground motions in the near-fault region. Journal of Soil Dynamics and Earthquake Engineering. 24, 815-828, 2004.
[7] Soleimani Amiri, F., Ghodrati Amiri, G., Razeghi, H.: Estimation of seismic demands of steel frames subjected to near-fault earthquakes having forward directivity and comparing with pushover analysis results. Journal of the Structural Design of Tall and Special Buildings, 2012., DOI: 10.1002/tal.747

[8] Anderson, J.C., Bertero, V.V.: Uncertainties inestablishing design earthquake, Journal of Structural Engineering, ASCE 113(8): 1709-1724, 1987., DOl: http://dx.doi.org/10.1061/(ASCE)07339445(1987)113:8(1709))

[9] Hall, J.F.: Seismic response of steel frame buildings to near-fault ground motions. Report No.EERL 97-05, California Institute of Technology, Pasadena, California, 1997.

[10] Sehhati, R., Rodriguez-Marek, A., ElGawady, M., Cofer, W.F.: Effects of near-fault ground motions and equivalent pulses on multi-storey structures. Journal of Engineering Structures. 33, 767-779, 2011., DOI:10.1016/j.engstruct.2010.11.032

[11] Özhendekci, D., Özhendekci, N.: Seismic performance of steel special moment resisting frames with different span arrangements. Journal of Constructional Steel Research. 72, 5160, 2012., DOI:10.1016/j.jcsr.2011.10.002 
[12] Mortezaei, A., Ronagh, H.R., Kheyroddin, A., Ghodrati Amiri, G.R.:Effectiveness of modified pushover analysis procedure for the estimation of seismic demands of buildings subjected to near-fault earthquakes having forward directivity. Journal of the structural design of tall and special buildings, 2009., DOI: $10.1002 /$ tal. 553

[13] Yaghmaei-Sabegh, S., Alizadeh, H.M.: Improvement of Iranian Seismic Design Code Considering the Near-Fault Effects. International Journal of Engineering, 2012., DOI:10.5829/idosi. ije.2012.25.02c.08

[14] Mostafaei, H., Kabeyasawa, T.: Effect of Infill Masonry Walls on the Seismic Response of Reinforced Concrete Buildings Subjected to the 2003 Bam Earthquake Strong Motion: A Case Study of Bam Telephone Center. Bulletin of Earthquake Research Institute, University of Tokyo. 79, 133-156, 2004.

[15] Soltanzadeh, H.R., Vahebi, M.A., Zarbakhsh, H.: The mechanism of building destruction in bam city. Lajavard: Tehran, 2005. (In Persian)

[16] Konagai, K., Yoshimi, M., Meguro, K., Yoshimura, M., Mayorca, P., Takashima, M. et al:: Strain Induced in Cracked Utility Poles and Damage to Dwellings from the Dec. 26, 2003 Bam Earthquake. Bulletin of Earthquake Research Institute, University of Tokyo. 79, 59-67, 2004

[17] Mostafaei, H., Kabeyasawa, T.: Investigation and Analysis of Damage to Buildings during the 2003 Bam Earthquake. Bulletin of Earthquake Research Institute, University of Tokyo. 79, 107$132,2004$.

[18] Sanada, Y., Niousha, A., Maeda, M., Kabeyasawa, T., Ghayamghamian, M.R.: Building Damage around Bam Seismological Observatory Following the Bam, Iran Earthquake of Dec. 26, 2003. Bulletin of Earthquake Research Institute, University of Tokyo. 79, 95-105, 2004.
[19] Hashemi, B.H., Hassanzadeh, M.: Study of a semi-rigid steel braced building damaged in the Bam earthquake. Journal of Constructional Steel Research. 64,704-721, 2008., DOI:10.1016/j. jcsr.2007.12.007

[20] Naeim, F.: The Seismic Design Handbook. $2^{\text {nd }}$ Edition. Kluwer Academic, New York, 2001

[21] Gerami, M., Abdollahzadeh, D.: Estimation of Forward Directivity Effect on Design Spectra in Near Field of Fault. Journal of Basic and Applied Scientific Research. 2, 8670-8686, 2012.

[22] Kramer, S.L.: Geotechnical Earthquake Engineering. Prentice Hall, New Jersey, 1996

[23] Baker, J.W.: Quantitative Classification of Near-Fault Ground Motions Using Wavelet Analysis. Bulletin of the Seismological Society of America. 5, 1486-1501, 2007., DOl: 10.1785/0120060255

[24] Saiidi, M., Somerville, P.: Bridge seismic analysis procedure to address near-fault effects. Research report of Caltrans Project, Nevada University (Reno), 2005.

[25] Standard No.2800, $3^{\text {rd }}$ Edition. Iranian Code of Practice for Seismic Resistant Design of Buildings. Ministry of Housing and Urban Development of Iran, 2005.

[26] FEMA 356. Prestandard and commentary for the seismic rehabilitation of buildings. Federal Emergency Management Agency, 2000.

[27] International Conference of Building Officials. Uniform Building Code (UBC97). Whittier, California, 1997.

[28] Iranian national regulation of buildings, Section $10^{\text {th }}$. Design and construction of steel buildings. Ministry of Housing and Urban Development of Iran, 2008.

[29] Hibbeler R.C.: Structural Analysis. 5 ${ }^{\text {th }}$ Edition, New Jersey: Prentice Hall, 405-427, 2001. 